Marquette University

e-Publications@Marquette

$11-30-2013$

\title{
The Anthropology of Family Business: An Imagined Ideal
}

Alex Stewart

Marquette University, alex.stewart@marquette.edu

Published version. "The Anthropology of Family Business: An Imagined Ideal," in SAGE Handbook of Family Business. Eds. Leif Melin, Mattias Nordqvist and Pramodita Sharma. Newbury Park, CA: Sage Publications, 2013. Publisher Link. (C) 2013 Sage Publications. Used with permission. 


\title{
The Anthropology of Family Business: An Imagined Ideal
}

\author{
Alex Stewart, Marquette University \\ Forthcoming in L. Melin, M. Nordqvist, \& P. Sharma (Eds.), \\ SAGE Handbook of Family Business, Newbury Park, CA: Sage.
}

\section{Introduction}

\section{Anthropology: An Underutilized Resource}

Cultural and social anthropology can advance family business studies thanks to well developed literatures in three areas: kinship theory, relevant research, and ethnography (up-close field research using participant observation). Despite these potential benefits, the discipline remains an "unutilized resource for advancing the field of family business studies" (Stewart, 2003, p. 383). Although it shares central interests with family business scholars (Rutherford, 2010; Stewart, 2008) it has not been widely utilized (Wigren, 2007). Searching the abstract of family business journals (largely Family Business Review) for a variant of "anthropology" uncovers just one article. Searching the full text uncovers 21 , largely incidental, references. More generally, anthropologists and business scholars have, since the 1960's, largely ignored one another (Jordan, 2010; Rosa \& Caulkins, 2013; Sunderland \& Denny, 2007, pp. 28-32).

How to make progress. How could the promise of the anthropology for family business be better fulfilled? For scholars brave enough to take on this task, two prerequisites stand out. First, they should familiarize themselves with anthropological findings and concepts. They should learn kinship theory and study relevant ethnographic works. They should then adapt this knowledge to family business by asking fundamental questions about kinship in connection with business. This would require attention to sources of solidarity and conflict, to cultural variation, 
and to the lived experience of kinship. Such a preparation is the subject of Part One of this chapter.

Second, family business scholarship should be methodologically sound and suited to family business studies. Methodology in anthropology is less well understood than in, say, economics or psychology. Therefore, Part Two addresses this concern. It focuses on five "tactics" for ethnographic method in Stewart (1998), applying them to issues in the family business field. It also addresses the need for cross-disciplinary study.

Business school researchers with these competencies could make outstanding scholarly contributions. Their writings could also unveil real-world details to capture the imagination of practitioners. These points are related. Up-close field research explores in depth the lived world of practitioners, uncovering the "complex and tacit processes" of family firms (Nordqvist, Hall \& Melin, 2009, p. 295) that often go unnoticed in our journals. Examples discussed below include "betrayal as a force of production" (Yanagisako, 2002), "strategies of heirship" (Goody, 1976), and behind-the-scenes roles of women in apparently male dominated cultures (Hamabata, 1990). These examples apply to Italy and Japan, reminding us that anthropology's cross-cultural perspective militates against ethnocentrism. Moreover, anthropological findings about kinship complement the strength of family business research, which is more discerning about business than family matters (Stewart, 2008; Stewart \& Hitt, 2012).

\section{Part One: Preparing to Contribute}

Before launching into anthropological research in family business, scholars will also need a thorough preparation in the relevant literatures. How should they begin this preparation?

\section{Familiarity with Relevant Ethnographies}


Preparation could start with readings in the most developed, closely relevant field in anthropology. However, much of this field - kinship theory - would appear too opaque and exotic on first exposure (Patterson, 2005; Peletz, 1995). If scholars began instead with relevant ethnographies they would simultaneously start to learn kinship theory. These texts could also fire their ambitions and suggest possibilities for their own work (Van Maanen, 2011).

Unfortunately, I know of no book-length ethnographies of family business at the firm level. This contrasts with ethnographies of non-family firms (Hodson, 1998; Morrill \& Fine, 1997). Particularly lacking are in-depth scholarly studies on both kinship and business within individual firms (Nordqvist, Hall, \& Melin, 2009). Ram (1994) and Helin (2011) are qualified exceptions; they studied more than one firm but focused on one in each case. Family business ethnographies typically focus on multiple firms in industry clusters. These include Italian footwear (Blim 1990) and silk (Yanagisako, 2002) clusters, and emigrant Chinese in the leather goods (Oxfeld, 1993), textiles (Wong, 1988) and take-away restaurant trades (Song, 1993).

Ram (1994) and Yanagisako (2002) are relatively attentive to business issues, and highly recommended. Yanagisako conducted high quality fieldwork, reflected in compelling accounts of several family firms. She is insightful on notions like "the conundrum of the secondgeneration self-made man" (pp. 90-92) and "betrayal as a force of production" (Chapter Four). By the latter she means familial creative destruction:

In later years, as the firm matures and begins to bring in members of the second generation, limitations to firm growth and expansion fuel sentiments of distrust and suspicion, which operate as forces for the division of the firm, the diffusion of technology, and the destruction of families. Out of these processes emerge new firms, new families 
and new solidarities (2002, p. 115; see also Goody, 1996, pp. 141-145, 155, 203; Kasdan 1965).

Two books about Japanese family businesses by Japanese-American scholars, Hamabata (1990) and Kondo (1990), are more typical of ethnographies of family firms, because neither offers much insight into business as such. Their focus - Hamabata's especially - is on the family. Nonetheless, both demonstrate the value of studies that examine businesses from the family perspective. They reveal a complex "set[s] of mutual connections" between "market [and] family" (Davidoff \& Hall, 1987, p. 32). Hamabata, for example, found that wealthy Japanese women conducted economic transactions through their natal kin. This was interesting and unexpected in a strongly patrilocal society; i.e. brides leave the geographic area of their families of orientation and affiliate with their husband's kindred instead (1990, p. 28).

A widespread finding in historical and ethnographic studies is that while women apparently play only private, domestic roles, they nonetheless influence business and public affairs, often through female only networks (Davidoff \& Hall, 1987, pp. 202, 227; also Bruun, 1993, p. 22; Colli, Fernández Pérez, \& Rose, 2003; Farrell, 1993, Chap. 4; Lomnitz \& PérezLizaur, 1987, p. 118; Ram, 1994, pp. 132-136; Robertson, 1991, p. 41). These findings offer insights into the linkages of business and kinship. Unfortunately, few studies examine the kinship-business connection in depth for the implications of this connection for the business itself.

\section{Knowledge of Kinship Studies}

"Kinship", "family", "household". Making sense of kinship writings requires an understanding of the relationships between "family," "kinship," and "household." "Kinship" can 
be defined as "the network of genealogical relationships and social ties modeled on the relations of genealogical parenthood" "as culturally defined by the society involved" (Holy, 1996, p. 40; Good, 1996, p. 312). The "systems" formed in this way "divide people into categories of kin, and then define marriageability in terms of these categories. They define descent, if you like, and legislate alliance" (i.e. marriage); they are thus "the assortive mating systems of the species" (Fox, 1983, pp. 2, 1).

A universally applicable definition of "family" is elusive (Creed, 2000). "People know what they mean when they use the word family, and the meaning is usually clear to others by the context... but most would find it difficult to define [the word] precisely" (Pine, 1996, p. 223). Its meanings are variable and often fuzzy (Davidoff \& Hall, 1987, pp. 31, 216; Stafford, 2000). With these qualifications, the effort by Harrell (1997) is helpful. He sees the family as a subset of kinship: "kinship principles have ramifications beyond the family... The family is a special type of kinship group, one consisting if close relatives in close cooperation in daily life" (1997, p. 5).

"Households" have been proposed as more useful alternative than "families" for family business scholarship (Aldrich \& Cliff, 2003). Certainly, the physical and human arrangements of households are important variables (Blim, 1990; Bruun, 1993; Yanagisako, 1979). Unlike families, however, households are not subsets of kinship systems but, being defined by function and by residence, include such non-kin as servants and boarders, and comprise overlapping subsets within (extended) families (Brettell, 2002).

Cross-cultural variation. Ethnographies are more entertaining than kinship theory, but there is no escaping the constructs of the field (e.g., "affinity": ties through marriage). Moreover, familiarity with kinship theory alerts us to the range of human variation. Kinship 
systems share commonalities and universal constraints (e.g. the length of the human lifespan; Harrell, 1997 and Sangren, 2009), but they vary in many ways, even in the same country at the same time (Yanagisako, 1978). This variance can help family firm scholars to minimize ethnocentric assumptions about human possibilities. For example, family business scholars almost never study the practices of marriage "payments": neither "dowry" nor "brideprice" are found in the full texts of journals with "family business" in their names (ProQuest, 5/24/2012). Yet these practices involve "substantial" transfers of wealth and are current in both India and China (Brown, Bulte \& Zhang, 2011, p. 140; Anderson, 2007).

Other variable properties of kinship systems affect family firms. Examples include the modes of transmitting property or office, the cultural understanding of "family" itself (Shimizu, 1991), rules of marriage and affinity (Shapiro, 1997; Stockard, 2002), and gender and sex role expectations (Ortner, 1996; Stone, 2010). Crucially for entrepreneurs, the potential for discretion in treatment of kin also varies (Scheffler, 2001; Stewart, 2010). Little wonder that we find that family firms vary across multiple dimensions (Goody, 1996; Stewart \& Hitt, 2012; Yanagisako, 2002).

Old" scientific and "new" humanistic kinship studies. A source of confusion for newcomers to kinship theory is disagreements between the "old" and "new" kinship studies. This distinction parallels older and newer modes of anthropology. Although these distinctions are not clear-cut they are widely encountered. The "old" kinship studies tend to adopt what Van Maanen (2011) termed "realist tales" while the "new" ones adopt such experimental modes as "confessional", "impressionist", "critical" and "literary tales".

These distinctions center on the tension within anthropology between science and humanism (Eriksen, 2006, pp. 13, 25, 32-34; Johnson \& Johnson, 1990; Malkki, 2007). 
Stereotypically, social scientific ethnography pursues naturalist documentation; on the other hand, humanistic ethnography pursues cultural critique or art, or both (Armstrong, 1971, pp. 80100; Lett, 1997, pp. 1-19; Mulligan, 1987). Scientific ethnography aims to be objective, comparative, realist and focused on social processes; humanistic ethnography to be subjective, particularistic, interpretive, and focused on lived experiences (Patterson, 2005; Peletz, 1995). This distinction is demonstrated by quotes from two recent ethnographies, both of which concern inter-connections between local and global economic forces:

Artesanías can be lucrative. A sweater wholesaler generally makes a profit of $\$ 1$ per sweater, and some make twice that, selling 5,000 to 250,000 sweaters annually. This is impressive in a country where the average annual per capita income has hovered around $\$ 1,100$ since the end of the 1980s according to World Bank statistics (Meisch, 2002, p. $78)$.

The universal bridge to a global dream space still beckons us. The bridge might take us out of our imagined isolation into a space of unity and transcendence: the whole world. We find ourselves like a man looking out from his parochial island toward the vast but hazy world of the mainland. The bridge of universal truths promises to take us there. Yet... we become hardened, or, alternatively, we are overcome with grief and anger (Tsing, 2005, p. 85).

This latter passage (clearly) reflects a humanistic anthropology and is reminiscent of an early vision of such an anthropology by Wagner (1979, p. 10), who called for "appreciating our 
species quest for meaning and all the elusive ghosts - responsibility, empathy, justice, awe, creativity, beauty, the numinous - that go with it, and identifying ourselves with that quest."

These distinctions are not always so apparent; many ethnographies have elements of science and of art (Wagner, 1979). Some "old” kinship studies include excellent treatments of "new" kinship issues (compare Fortes, 1949), and Geertz, the most influential advocate of humanism (Kuper, 1999, Chap. 3), was skeptical about postmodernism and adamant that his approach was scientific (Geertz, 1973, pp. 15, 24). Further, "new” kinship studies are heterogeneous and some current kinship theory is avowedly scientific. An example of the latter is the network analysis of kinship by White and his colleagues (e.g., White and Johansen, 2006).

However, the differences between humanistic and scientific approaches are not merely rhetorical, nor do they affect only extreme advocates of one approach or another. Questions about the purpose of scholarship divide important kinship scholars. For example, should scholars aim to approximate "truth", or is that a naive goal? What role, if any, should data, or non-anthropological theories, play in kinship studies? Thus, the field includes lively debates by proponents of one persuasion or the other (Holy, 1996, Chap. 7; Scheffler, 2010).

Partisanship can roughly be inferred by the critique or approbation of the work of David Schneider. His work was an influential precursor of the new kinship studies (Feinberg, 2001; Shimizu, 1991). Schneider was a student of Parsons, whose own work sought to untangle the relationships between four "system levels": culture, social relationships, psychology and biology (Parsons, 1951). However, Schneider reduced the anthropological study of kinship to culture sui generis (Kuper, 1999, Chap. 4; Godelier, 2011, pp. 19-22, 69, 104). The implication was that central issues for family business, connections between business and kinship (both of which involve culture but also personality and social relationships) were out of bounds. Schneider also 
combined a sweeping rejection of prior ethnographies as projections of western presumptions, with a disregard for evidence in his own work (Schneider, 1995, pp. 209-212). His later writings, helped persuade many anthropologists (except in France; Patterson, 2005) to abandon kinship as a topic of inquiry (Carsten, 2000).

\section{Focus on Important Questions}

Preparation specific to family business. A relevant anthropology of family business asks fundamental questions. Why does kinship exist; how does this generate ambivalence in relationships; how does this affect family firms? (Stewart \& Miner, 2011). What is the relationship between kinship and other relations, such as economic, religious or political (White \& Jorion, 1996)? These questions have long been debated. Some have argued that kinship relations are merely epiphenomena or idioms about something else. A prominent example was a book about "the relation between land use and kinship within [a particular] territorial framework", in which Leach (1961, pp. 299, 305) announced "that kinship systems have no 'reality' at all except in relation to land and property. What the social anthropologist calls kinship structure is just a way of talking about property relations which can also be talked about in other ways".

As Godelier cautioned, "this was a provocation of the sort Leach was fond of launching" and it led, with other writings of the era, to further discussion of "the links between kinship and economy, power, religion, etc.” (2004, pp. 16, 19, also 485). Godelier's own efforts to answer this question are worth an effort at a précis. In his view,

Leach missed the essential point. The language of kinship is inevitable in so far as, from a person's birth, kinship relations are a source of right and obligations that precede any 
contract... The great strength of kinship is that it embeds these rights and obligations in relationships... which, for some, are nurturing, protecting, and which provide the primary material and social support that greets the person at his or her birth (p. 314).

In short, there are reasons that kinship and not something else provides the idiom for the most valued obligations in a culture (Bloch, 1971; Bloch \& Sperber, 2002; Stewart \& Miner, 2011). Godelier does not, however, infer that kinship plays a pre-eminent role amongst the other "practices and areas of life" (72), nor that kinship can itself be the basis for the organization of a territorial group. Such a role can only be played by relationships that cut across all its members, and these relationships in his view are political and religious. These latter two "co-opt" (p. 82) or "come to reside" (p. 480) "in a given kinship relation and make all kinship relations serve their own functioning and reproduction" (p. 480; alternatively political-religious relations "take over", pp. 481, 483: "investissent", p. 646 of the French edition). Only these non-kinship relations "have the capacity to create a general state of interdependence between all of the groups and individuals... and which make the society into a whole... This is something kinship per se... is precisely incapable of doing" (p. 483).

Godelier's thesis holds more than theoretical interest. "Kinship relations everywhere" he claims "can and especially must support" those political-religious relations that have infiltrated them (p. 496; we must ask again why it is kinship and not something else that must do this). The consequence, he argues, is that non-kinship (or akinship) social relations are transformed into:

the stuff of kinship. And everything that falls under kinship is transformed into relations between the sexes in the first place and then between parents and children. And finally 
everything having to do with kinship is imprinted into sexed bodies from birth and becomes an attribute of a person's sex... [and are] metamorph[ized into] 'gender' differences" that are perceived to characterize "not only men and women but myriad beings that populate the universe (p. 496).

It follows (pp. 496-497), that revolutions in the domain of sex roles must be fought primarily on the terrain of politics and also of religion.

The kinship-business interface. A related question for family business scholars is explaining the process by which entrepreneurial opportunities derive from the kinship-business interface (Johannisson, 2002). Anthropological answers to this question require assumptions about the ways the "domains" of kinship and business are distinct. They also require reference to foundational work in the anthropology of entrepreneurship, according to which entrepreneurs find value from creating bridges between different spheres of exchange (Barth, 1967). As Stewart and Hitt elaborated (2012, p. 72):

Discrepancies in evaluation can arise because of constraints on exchange - in an obvious example, familial love is not widely regarded as saleable. They can also arise simply from differing perspectives. For example, impecunious noble families may enter into marital exchanges with the newly wealthy, trading prestige for commercial opportunities or capital, and vice versa (McDonogh, 1986). 
Numerous ethnographies have contributed to our understanding of this process at the businesskinship interface (Bruun, 1993; de Lima, 2000; Lomnitz \& Pérez-Lizaur 1987; Marcus \& Hall 1992; McDonough 1986; Ram 1994).

\section{Attention to Lived Experiences}

Exploring the business-kinship interface requires attention to everyday experiences of kinship. For this, the "new" kinship studies are more attentive, examining emotional qualities like ambivalence (Lambek, 2011; Peletz, 1995). A proponent argues, “To understand relatedness, and to understand the place of relatedness in dynamic relationships that converge in the domestic arena yet extend beyond it, requires detailed analysis of spoken and unspoken meanings, the micropolitics of interactions, and historical structurings of power in particular places at specific moments" (Van Vleet, 2008, p. 195; also Godelier, 2011, p. 78). Compared with the focus in the "old" kinship studies on structure, function and "the politico-jural aspect of kinship" (Holy 1996, p. 51), more focus is on human agency (willfulness and strategizing: Viazzo \& Lynch, 2002) and "everyday cooperation, negotiation, and competition" (Yan, 2001, p. 239).

An exemplar of the focus on lived kinship is Stafford's paper on "the processual and creative aspects of Chinese kinship and relatedness" (2000, p. 38). He argues for four interconnected and "equally forceful... systems of Chinese relatedness": not only patriliny and affinity (the "old" kinship topics), but also " "the cycle of yang' (which centers mostly on parentchild relationships) and 'the cycle of laiwang' (which centers mostly on relationships between friends, neighbours, and acquaintances"' (as above). These latter two systems are ignored in formalist analyses that render the familial and domestic as separate from kinship. Moreover, 
these two systems - and laiwang in particular - are important for understanding the opportunities for discretion facing Chinese entrepreneurs.

Attention to general patterns at the expense of everyday, "domestic" kinship misses vital concerns in family firms. For example, Hamabata found that the wife of a Japanese company president believed that "for their household [i.e., their ie]... the objective was to bring in talent through marriage and adoption" (1990, p. 44). These are typical Japanese "strategies of heirship" (Goody, 1976), amenable to analysis from afar. However, Hamabata's fieldwork in the domestic realm led him to an observation attainable only that way: her daughter strongly objected to becoming, effectively, a household head - "a man in the guise of a woman" - wishing instead to be "a true hana-yome (a newlywed bride)" (p. 45). Both aspects of this vignette, the pattern of discretion in Japanese family firms of incorporating adopted sons-in-law into the ie, and the way it played out in action, are needed for an understanding of these family firms.

\section{Alertness to Sources of Solidarity and Conflict}

For the entrepreneur, kinship can be a resource, a hindrance, or irrelevant (Wallman, 1975). Relatives can be the most reliable, long-term sources of support (Bloch, 1973); they can be the most insidious of foes (Gordon \& Nicholson, 2008). Relationships with kin can be infused with deeply felt obligations, or entirely instrumental (Stewart, 2003). How can we explain the way the range of possibilities plays out on the ground? The answer depends on the context, so a first step is attentiveness to ethnographic detail. For example, Peletz (1995, p. 355) urged us to learn "more about how and why Chinese [family firms] are able to overcome familial ambivalence in the context of economic cooperation when many other groups (e.g. Malays, Javanese, and Thais) are not" (Peletz, 1995, p. 355). 
Peletz speaks to a core question for family firms: how and why can kinship be a source of solidarity but also of conflict (Stewart, 2003). We have noted the role of differential growth in kin compared with wealth (Yanagisako, 2002). As this implies, the answer requires understanding of the links between kinship and property, of succession and inheritance (dowry, bridewealth), and of formal and realized law (Anderson, 2007; Hann, 2005). Overarching all of these topics is differential power in sex roles (Godelier, 2011, pp. 74, 80-85, 483, 496-497).

Ethnographic studies of the role of property include the example of "betrayal as a force of production" (Yanagisako, 2002) noted above. Another is Greenhalgh's (1994) article on power differentials within the family. Another is Goody's (1976) works on "strategies of heirship" or ways to cope with a shortage of heirs. Strategies include marital choices (e.g. serial monogamy, polygyny) and incorporative practices such as adoption (Stewart, 2010). A related topic is the process of entrepreneurs who dis-embed from kinship obligations at one stage of building their ventures, but re-embed as honored community leaders later on (Hart, 1975; Stewart, 1990).

\section{Part Two: Well Executed Ethnography}

Criteria for ethnographic method. Having prepared themselves with their readings, anthropologists who study family business also need to prepare methodologically. Ethnography, or inquiry based on participant observation, is the core method of social and cultural anthropology. Perhaps I should say set of methods, plural, due to the medley of approaches (Adler \& Adler, 2008; Malkki, 2007). Anthropological ethnographers lack a consensus on, or even an interest in, the criteria and standards for appraising these productions (Briggs, 2007; Werner, 1998; Wigren, 2007). In an effort to fill this void, I have proposed that ethnography should be judged by three epistemic values or criteria, provided that the ethnography aims to 
approximate scientific truth (Stewart, 1998, p. 14; my editors believed that these criteria apply equally to "postmodern, poetic, and other nonscientific ethnographies", p. v).

The three criteria are (1) descriptive truth (or "veracity"); (2) transcendence of perspectives - i.e. relative impartiality - (or "objectivity"); and (3) specifying the applicability of its insights to other settings (or "perspicacity"). Their "quantitative" equivalents are validity, reliability and generalizability. In Stewart (1998), I noted the challenges in research that make the criteria hard to satisfy, and the most effective "tactics" that help to overcome these challenges. Here, our focus is on the latter.

\section{Veracity (Akin to Validity)}

Validity seems an innocuous criterion for ethnography. However, I agree with Wolcott (1994) that the term is too colored by connotations of psychometrics and propose the alternative term "veracity" (Stewart, 1998, pp. 14-15). By this I mean descriptive truth. This goal is never fully achieved, but attempts to attain it are critical. Without some success in this direction no other criteria need concern us (p. 18). Due to the challenges confronting its attainment, both in the field setting and in the person of the researcher (pp. 19-20), I propose several "tactics", of which the most crucial are prolonged fieldwork, good participative role relationships, and the search for reorienting observations.

Tactic one: Prolonged fieldwork. Most "qualitative" studies in management conform to publish or perish norms by adopting "rapid appraisal" approaches (Stewart, 1998, p. 20; Morrill \& Fine, 1997). This is unfortunate (Werner, 1998). Prolonged fieldwork of 12-18 months or more "is the single most potent tactic that ethnographers have to enhance veracity" (Stewart, 1998, p. 20). Without it, researchers miss witnessing cultural and interpersonal subtleties. They miss chances to get "sufficiently "behind the scenes" in, for example, succession processes (Lam, 
2011) where they might witness discrepancies between actions and words (Hodson, 1998, p. 1191). They miss chances to notice disconfirming observations and multiple perspectives. For example, Chagnon (1968) and Godelier (2011, Chap. 2) misunderstood kinship systems early in their fieldwork.

Tactic two: Helpful participative roles. Another reason to persist in fieldwork is that ethnographers often need to assume a sufficiently "active" or "complete" membership role; (Adler \& Adler, 1987). The role of "researcher" is insufficient to "generate opportunities for inquiry... [that provides] exposure to interactions and performances, in a wide variety of naturalistic, backstage social contexts [preferably with] access to a wide variety of actors" (Stewart, 1998, pp. 23-24; also Mosse, 2006). Some sort of "apprenticeship" role is ideal (Coy, 1989), though access to such roles may be difficult.

Difficulties with Access may account for the dearth of ethnographies of family firms. Access into any organizational sites can be challenging (Feldman, Bell, \& Berger, 2003). Access into family firms is particularly challenging. Families themselves often maintain "relatively closed and highly protected boundaries" (Daly \& Dienhart, 1998, p. 102). Gatekeepers of family firms may be accustomed to privacy, and concerned that sensitive family matters could be publicized if they granted researchers up-close, long-term access.

Opportunistic use of pre-existing connections such as consultancy roles may be needed, as it was for Dalton and other organizational ethnographers (Helin, 2011). One such form of access that suits family business research is native or auto-ethnography, such that insiders study their own firms (Jackson, 2004; Jacobs-Huey, 2002). Learned's dissertation (1995, pp. 49-55) is an example (e.g. Learned painfully dismissed his father from the board of directors). Another possible design is the study of family firm individuals, not firms, along the lines of Harper's 
(1987) photo-ethnographic study of a mechanic, or Keesing's (1978) oral history of a Melanesian entrepreneur.

Tactic three: Search for reorienting observations. "Longer periods of fieldwork... increase variation in what could be observed and in the capacities to notice" (Stewart, 1998, p. 21). Therefore, prolonged fieldwork enables another tactic, that of good membership roles, and also a third tactic, that of seeking reorienting observations (Campbell, 1975). This latter tactic relies on the persistent "suppositional work" of recognizing one's emerging expectations and seeking to discover surprises or reorientations in our developing understandings (Locke, 2011a, p. 631). It is a comprehensive search for comparisons and connections among phenomena. In Mills' terms (2000/1959, p. 200), the scholar puts "together hitherto isolated items, by finding unsuspected connections."

Implementing this tactic is difficult, due to our inclination to notice "confirming rather than disconfirming evidence" (Creswell \& Miller, 2000, p. 127). It is facilitated by habits such as rendering observations explicit, by using photographs (Collier \& Collier, 1986; Harper, 1987) or (more commonly) fieldnotes (Emerson, Fretz, \& Shaw, 2011; Sanjek, 1990b). The search for reorienting observations may also be enabled, post-fieldwork, by in-depth indexing of data in computer retrieval programs (Friese, 2012; Stewart, 1998, p. 53).

\section{Objectivity (Akin to Reliability)}

Once you have stayed long enough in appropriate roles, noting many reorienting observations, you launch your "write-up", presenting the perspectives of insiders from whom you have learned. At this point, the criterion of objectivity poses a question: which perspectives? Have you depicted, for example, only the views of "key informants" among the leaders (Aunger, 2004)? Or only the views of disenchanted branches of the family? Or only the views of males, 
or females? Or only family and not non-family, members? A study that is "more objective... [is] less dependent on a singular perspective" (Hegelund, 2005, p. 663). It "transcends" the perspectives of just the researcher and just of (certain) informants (Stewart, 1998, p. 16; Hunt, 2003, Chap. 8). You cannot depict all perspectives equally. But you can sample multiple perspectives from multiple informants (Goldthorpe, 2000, pp. 74-79; Heider, 1972). You can try systematically to cover the "range of variation" amongst them (Werner, 1998; Werner \& Bernard, 1994, p. 9).

Tactic four: The ethnographer's path. You can also reveal for readers which perspectives you have encountered and represented. You do so by depicting what Sanjek (1990a, pp. 398-400) calls 'the ethnographer's path', the network of informants that the researcher engages" (Stewart, 1998, p. 34; also Werner, 1998). This depiction can be implicit in your account; explicit discussions are unusual (Moffat, 1992). The way you represent the path is certainly less important than the path itself. But only if you make it transparent can others evaluate the biases that affect yours or any ethnography. Only then can they learn "the range of variation in perspectives that were witnessed" (Stewart, 1998, p. 35). Only then can they evaluate your study's objectivity.

\section{Perspicacity (Somewhat Akin to Generalizability)}

Perspicacity is the closest analogue to external validity or generalizability that ethnographers can aim for. But it is not the same. It has two elements: (i) the generation of insights that (ii) can be utilized in studies in different spatial, temporal and cultural contexts. In short, it "is the capacity to produce applicable insights" (Stewart, 1998, p. 47). The primary goal is generation of insights, and a secondary goal is their representation so as to help others to develop insights of their own. The first, primary, goal is the object of tactic five: "exploration." 
Tactic five: Exploration. "Exploration" is a process of discovery. It "is a quest; it is not a technique that lends itself to tidy or comprehensive prescriptions" (Stewart, 1998, p. 57). To the contrary, it calls for "imagination" (Locke, 2011a, p. 614; Stebbins, 2001, p. 230). Mills (2000/1959, p. 201) expressed it this way: "Imagination is often successfully invited by putting together hitherto isolated items, by finding unsuspected connections". He recommended disconnecting and reconnecting theories. Besides creativity and imagination, then, the key construct here is "connections."

Connections are of two types. In one type, a modal observation of a cultural object, say, a post-marital residence rule, is connected with another observation as a matter of comparison or contrast. In the other type, it is placed in a wider context, another aspect of social life that impinges on the modal object, such as patterns of inheritance. Both of these connections are needed to answer Becker's question "What is this a case of?" (Ragin, 1992, p. 6). And as Locke (2011b, p. 89) argues, to answer this question we need a wide range of "data and... cycles of generating and trying out ideas against them." We need to make multiple connections with comparisons and contexts.

Why this should be stems from the way ethnographers make sense of observations. As Geertz (1974) demonstrated, we have to consider multiple examples of a cultural object to discern what it is, how it compares with similar cultural objects and how various instances compare with one another (see also Urban, 1999). These comparisons derive from within-site observations, ethnographies about other cultures, and personal experiences and preconceptions (Barth, 1999; Godelier, 2004, pp. 12; 70-72; Mills, 2000, p.195). The need for connections also derives from the nature of an insight, in the sense the word is used here. 
Middle range theories An insight is not an observation pure and simple. It is not a mere social "fact'. It is an "unexpected," non-trivial patterned set of social facts or observations that can fruitfully be compared with observations in other times and places (Arnould, Price \& Moisio, 2007, p. 107). Ethnographic insights of this sort tend to be middle-range theories. An example is Goody's conception of "diverging devolution" (bilateral inheritance: inter-generation transmission of property to both sexes), which he associates with "dowry, with monogamy, with in-marriage of various sorts, and with kin terms that differentiate the nuclear family from more distant kin" (Goody, 1969, p. 55; also 1976; Hann, 2008). Goody's theory was developed from the systematic comparison of multiple ethnographies, using the Human Relations Area Files (see Ember \& Ember, 2009). Other examples of middle range theories derived from localized fieldwork include Yanagisako's (2002) betrayal as a force of production, and Barth's (1967) entrepreneurship as the bridging of spheres of exchange. The example I used in Stewart (1998, pp. 48-51, 62, 82-83), is Aubrey Richard's (1950) “matrilineal puzzle”, which holds that matrilineal systems have structural challenges requiring resolution.

For reasons of space and readers' interests, ethnographers rarely spell out the connections that generated their concepts. However, Yanagisako hints about how she recognized "betrayal as a force of production" (2002, Chap. 4). She asked herself comparative questions. Which informants tended most to use the common phrase "parenti, serpenti [relatives are snakes]" (p. 110). Who tended to deny that kinsfolk are relatives? Who was depicted as a non-relative in one context but as a relative in another? What level of wealth among family firms characterized those who most used this expression? As these examples demonstrate, comparative questions lead to contextual questions. The syndrome she depicted was most pronounced amongst those 
firms lacking the wealth to provide venture opportunities for all descendants and that "relied on relatives for technical labor rather than financial capital” (p. 116).

Contexts. Whenever the topic of kinship is explored, comparisons lead to other contexts. Family business researchers should be alert to the possibility that any set of observations whether categorized as a matter of ritual and ideology, politics and law, ecology, labor needs, and so on - might prove important for explaining the family (Yanagisako, 1979). Kinship is notoriously inter-connected with other social and cultural topics (Creed, 2000; Godelier, 2011; Peletz, 1995). For example, a study of "the function of kinship in politics" concluded that understanding requires attention to other social categories such as factionalism, religious affiliation, class and ethnicity" (Buessow, 2011, p. 108). Not every connection will be illuminating, but certain connections, as those with demography, sex roles, and modes of access to property and other rights should be entertained (Scheffler, 2001; Yanagisako, 1979).

Consider the example above from Hamabata (1990, pp. 41-46), in which a president's daughter resisted marrying a muko-yooshi (male bride) to succeed to her father's status, her only brother being indulged and incapable. Among the comparisons needed for explicating this incident, we would need to know (as Yanagisako did) the level of wealth of the firm. Only those successful enough to attract a capable son-in-law might also be able to provide for the independence displayed by the daughter. We would have to ask about the daughter's gender ideology, in which she saw the burdens of an oyome-san (bride), under the thumb of a mother-inlaw in a stranger's household, to be less than those of a "household headship in the guise of the household wifeship... [and] denying the very essence of femininity" (p. 45). We would have to make comparisons with other potential brides as well as forms of gender ideology. We would 
also consider the implications for "strategies of heirship" (Goody, 1976). We would need to bear in mind the relative power of marriageable daughters as well as available sons-in-law.

An insight should be useful for others. As this example suggests, perspicacious middle range theories are amenable to disconfirmation or reconfiguration because they allow for corollaries. In the example of the matrilineal puzzle, one could propose that matrilineal systems are relatively unstable given certain residential patterns and contingencies; in the case of betrayal as a force of production, that later generation offshoots of family firms tend to be involved in disputes over intellectual property; in the case of Barth's theory of entrepreneurship as the crossing of spheres of exchange, that entrepreneurs are especially likely to be aware of more than one such sphere. The capacity of insights to be useful for later development has implications for how ethnographies should be reported. They should report sufficient detail for this purpose, ideally (perhaps) idealistically, enough that "all the contingencies that inhere in or affect their proffered constructs and theories [can be considered for] the potential reconstruction or disconfirmation [of your insight] by other scholars" (Stewart, 1998, p. 63).

Research tradeoffs. Perspicacity is the closest that ethnography comes to generalizability, but it is not the same. We learn about the actual behaviors and cultures of others using ethnography as our lens. However, we learn about the distribution and variance of behavior and culture with surveys as our lens. We cannot do both at once; surveys and fieldwork pull in incompatible directions (Van Maanen, 1975). Efforts have been made to merge the approaches (Aunger, 2004; Gravlee, Kennedy, Godov \& Leonard, 2009) but it is hard to overcome the tradeoffs of research. In Brinberg and McGrath's terms, only one of the goals of "generalizability, precision and realism can be maximized" (1985, p. 43). In Weick’s (1979, pp. 35-36) terms, we can maximize only two amongst the goals of being general, simple or accurate. 
The core of ethnography - up-close, unobtrusive observation and situated learning - does not generate generalizability. For example, the qualities that make for an excellent informant do not make for representativeness (Spradley, 1979, pp. 47-54). Moreover, "standardization of techniques" (Cohen, 1977, p. 245) would be needed for cross-cultural comparisons, if one were to directly feed data from various cultures into the same algorithms, without the need for another level of interpretation. The reason ethnographic standardization is a quixotic goal is the "complex relationships between indicators [which need to be "locally applicable"] and variables" (Cohen, as above). The former are often culture-specific, defying readily comparable measures. "Anthropology has not standardized its techniques... precisely because it values its own holistic richness and therefore requires culture-specific indicators, not cross-culturally applicable instruments" (as above).

Improvisation. For the problem of within-site variation, the solution in principle is random sampling of informants (Heider, 1972; Johnson \& Johnson, 1990). However, this solution does violence to the character of participant observation. Ethnographers who were in some sense insiders but who treated people randomly would soon lose their credibility. They also could not pursue disconfirming observations without prioritizing theoretically useful, not random, comparisons. The ethnographic "strategy" in fieldwork should be "seeking out diversity" (Barth, 1999, p. 82), not randomness. Further, this seeking must be opportunistic, given fieldwork realities. As Malkki (2007, p. 180) argues about the improvizational character of ethnography, the reason there is no "stable tradition with a fixed battery of methods... [is that] improvization $i s$ the tradition". Improvization is a reason there can be no fixed, singular ethnographic method, but rather "an open, flexible, context-dependent, and time-sensitive repertory of possibilities" (as above). 
Triangulate, if you seek generalizability. Goldthorpe (2000, p. 70) believes that ethnography can test "explanatory accounts" at the level of "the social processes through which... relations among variables are actually generated and sustained" - something surveys cannot accomplish. However, he holds that none of the ethnographic approaches to the "problems of variation across locales" (p. 79) is adequate. Sociology simply has not produced law-like theories that will, once observed in one locale, "necessarily be found [to apply] in all comparable locales" (p. 81). Therefore, theories produced from ethnographies must be tested with other means. Should you wish to learn about variability and distribution, non-ethnographic methods are needed (Werner \& Bernard, 1994). Ethnographers seeking generalizability need to triangulate (Scandura \& Young, 2000). Examples of triangulation, with representative surveys to test the external validity of ethnographic findings, include Hollos and Larsen (2004) and Ryan and Bernard (2006).

\section{Cross-Disciplinarity}

For these methodological reasons, a robust anthropology of family business does not rely only on ethnography. Moreover, this anthropology does not rely only on anthropology. It uses sociology, history, and possibly law and psychology (Godelier, 2011, p. 522; Stewart, 2008). Comprehensiveness and contextualization draw us to questions best studied in other disciplines (Malkki, 2007; Mills, 2000, p. 224). For example, "history and anthropology are in fact closely related" (Brettell, 2002, p. S46) and many relevant works cross across these two disciplines (e.g. Goody, 1996; Jones, 2006; Kuper, 2009; McDonough, 1986; Segalen, 1986; Watson, 1985). Of course, the business disciplines are also needed, because the family business field lies at the margins of kinship and business.

\section{What Can We Hope For?}


This chapter has offered an "imagined ideal" for the anthropology of family business. Scholars who follow its suggestions will make outstanding contributions, whether they are business school scholars who learn anthropology, or anthropologists who learn about business (Rosa \& Caulkins, 2013). Family business is a boundary-crossing field that calls for expertise in both familial and commercial domains. Family business research has been much stronger about business than it has about kinship (Stewart \& Hitt, 2012). Skewing away from kinship is particularly notable at the level of detail of a good ethnographic study. These details could refer to important business issues (e.g. the example of a daughter's unwillingness to marry a successor to her father). Sadly, few ethnographic studies of family firms have been very alert to business domain. Ideally, ethnographic writings would have the depth of real-world detail on both domains, so as to inform and to resonate with family business members as well as with scholars. Nordqvist, Hall and Melin argued that interpretive research has the "practical... goal" of helping practitioners to manage in their dynamic, "complex" worlds $(2009$, p. 306). This is the ultimate goal, the imagined ideal, for an anthropology of family business. 


\section{References}

Adler, P. A., \& Adler, P. (1987). Membership roles in field research. Newbury Park, CA: Sage.

Adler, P. A., \& Adler, P. (2008). Of rhetoric and representation: The four faces of ethnography. Sociological Quarterly, 49, 1-30.

Aldrich, H. E., \& Cliff, J. E. (2003). The pervasive effects of family on entrepreneurship: Toward a family embeddedness perspective. Journal of Business Venturing, 18, 573-596.

Anderson, S. (2007). The economics of dowry and brideprice. Journal of Economic Perspectives, 21(4), 151-174.

Armstrong, R. P. (1971). The affecting presence: An essay in humanistic anthropology. Urbana: University of Illinois Press.

Arnould, E. J., Price, L., \& Moisio, R. (2007). Making contexts matter: Selecting research contexts for theoretical insights. In R. W. Belk (Ed.), Handbook of qualitative research methods in marketing (pp. 106-128). Northampton, MA: Edward Elgar.

Aunger, R. (2004). Reflexive ethnographic science. Lanham, MD: AltaMira.

Barth, F. (1967). Economic spheres in Darfur. In R. Firth (Ed.), Themes in economic anthropology (pp. 149-174). London: Tavistock.

Barth, F. (1999). Comparative methodologies in the analysis of anthropological data. In J. R. Bowen \& R. Peterson (Eds.), Critical comparisons in politics and culture (pp.78-89). New York: Cambridge University Press.

Blim, M. L. (1990). Made in Italy: Small-scale industrialization and its consequences. Westport, CT: Praeger.

Bloch, M. (1971). The moral and tactical meaning of kinship terms. Man (N.S.), 6, 79-87.

Bloch, M. (1973). The long term and the short term: The economic and political significance of the morality of kinship. In J. Goody (Ed.), The character of kinship (pp. 75-87). London: Cambridge University Press.

Bloch, M., \& Sperber, D. (2002). Kinship and evolved psychological dispositions. Current Anthropology, 43, 723-748.

Brettell, C. B. (2002). Gendered lives: Transitions and turning points in personal, family, and historical time. Current Anthropology, 43 (Supplement), S45-S61.

Briggs, C. L. (2007). Anthropology, interviewing, and communicability in contemporary society. Current Anthropology, 48, 551-580. 
Brinberg, D., \& McGrath, J. E. (1985). Validity and the research process. Thousand Oaks, CA: Sage.

Brown, P. H., Bulte, E., \& Zhang, X. (2011). Positional spending and status seeking in rural China. Journal of Development Economics, 96, 139-149.

Bruun, O. (1993). Business and bureaucracy in a Chinese City: An ethnography of private business households in contemporary China. Berkeley: Institute of East Asian Studies, University of California, Berkeley.

Buessow, J. (2011). Street politics in Damascus: Kinship and other social categories as bases of political action, 1830-1841. The History of the Family, 16(2), 108-125.

Campbell, D. T. (1975). Degrees of freedom and the case study. Comparative Political Studies, 8, 178-193.

Carsten, J. (2000). Introduction: Cultures of relatedness. In J. Carsten (Ed.), Cultures of Relatedness (pp. 1-36). New York: Cambridge University Press.

Chagnon, N. A. (1968). Yanomamo: The fierce people. New York: Holt, Rinehart \& Winston.

Cohen, R. (1977). Comment on "Standardization and measurement in cultural anthropology: A neglected area." Current Anthropology, 18, 235-258.

Colli, A., Fernández Pérez, P., \& Rose, M. B. (2003). National determinants of family firm development? Family firms in Britain, Spain, and Italy in the nineteenth and twentieth centuries. Enterprise and Society, 4, 28-64.

Collier, J. Jr., and Collier, M. (1986). Visual anthropology: Photography as a research method. Albuquerque, NM: University of New Mexico Press.

Coy, M. W. (1989). Being what we pretend to be: The usefulness of apprenticeship as a field method. In M. W. Coy (Ed.), Apprenticeship (pp. 115-135). Albany: State University of New York Press.

Creed, G. W. (2000). "Family values" and domestic economies. Annual Review of Anthropology, 29, 329-355.

Creswell, J. W., \& Miller, D. L. (2000). Determining validity in qualitative research. Theory into Practice, 39, 124-130.

Dalton, M. 1959. Men who manage: Fusions of feeling and theory in administration. New York: Wiley. 
Daly, K., \& Dienhart, A. (1998). Navigating the family domain: Qualitative field dilemmas. In S. Grills (Ed.), Doing ethnographic research: Fieldwork settings (pp. 97-120). Thousand Oaks, CA: Sage.

Davidoff, L., \& Hall, C. (1987). Family fortunes: Men and women of the English middle class, 1780-1850. Chicago: University of Chicago Press.

Ember, C. R., \& Ember, M. (2009). Cross-cultural research methods, $2^{\text {nd }}$ Ed. Lanham, MD: AltaMira.

Emerson, R. M., Fretz, R. I., \& Shaw, L. L. (2011). Writing ethnographic fieldnotes, $2^{\text {nd }}$ Ed. Chicago: University of Chicago Press.

Eriksen, T. H. (2006). Engaging anthropology: The case for a public presence. New York: Berg.

Farrell, B. (1993). Elite families: Class and power in nineteenth century Boston. Albany: State University of New York Press.

Feinberg, R. (2001). Introduction: Schneider's cultural analysis of kinship and its implications for anthropological relativism. In R. Feinberg \& M. Ottenheimer (Eds.), The cultural analysis of kinship: The legacy of David M. Schneider (pp. 1-31). Urbana: University of Illinois Press.

Feldman, M. S., Bell, J., \& Berger, M. T. (Eds.) (2003). Gaining access: A practical and theoretical guide for qualitative researchers. Lanham, MD: AltaMira Press.

Fortes, M. (1949). The web of kinship among the Tallensi.. London: Oxford University Press.

Fox, R. (1983). Kinship and marriage: An anthropological perspective. New York: Cambridge University Press.

Friese, S. (2012). Qualitative data analysis with ATLAS.ti. Newbury Park, CA: Sage.

Geertz, C. (1973). Thick description: Toward an interpretive theory of culture. In C. Geertz, The interpretation of cultures (pp. 3-30). New York: Basic Books.

Geertz, C. (1974). "From the native's point of view": On the nature of anthropological understanding. Bulletin of the American Academy of Arts and Sciences 28, 26-45.

Godelier, M. (2004). Métamorphoses de la parenté. Paris: Fayard. Translated (2011) as The metamorphoses of kinship (N. Scott, Trans.), London: Versa.

Goldthorpe, J. H. (2000). On sociology: Numbers, narratives, and the integration of research and theory. New York: Oxford University Press. 
Good, A. (1996). Kinship. In A. Barnard \& J. Spencer (Eds.), Encyclopedia of social and cultural anthropology (pp. 311-318). London: Routledge.

Goody, J. (1969). Inheritance, property, and marriage in Africa and Eurasia. Sociology, 3, 55-76.

Goody, J. (1976). Production and reproduction: A comparative study of the domestic domain. Cambridge, UK: Cambridge University Press.

Goody, J. (1996). The East in the West. Cambridge, UK: Cambridge University Press.

Gordon, G., \& Nicholson, N. (2008). Family wars: Classic conflicts in family business and how to deal with them. London: Kogan Page.

Gravlee, C. C., Kennedy, D. P., Godoy, R., \& Leonard, W. R. (2009). Methods for collecting panel data: What anthropology can learn from other disciplines. Journal of Anthropological Research, 65, 463-483.

Greenhalgh, S. (1994). Deorientalizing the Chinese family firm. American Ethnologist, 21, 746775 .

Hamabata, M. M. (1990). Crested kimono: Power and love in the Japanese business family. Ithaca, NY: Cornell University Press.

Hann, C. (2005). A new double movement? Anthropological perspectives on property in the age of neoliberalism. Socio-Economic Review, 5, 287-318.

Hann, C. (2008). Reproduction and inheritance: Goody revisited. Annual Review of Anthropology, 37, 145-158.

Harper, D. (1987). Working knowledge: Skill and community in a small shop. Chicago: University of Chicago Press.

Harrell, S. (1997). Human families. Boulder, CO: Westview.

Hart, K. (1975). Swindler or public benefactor? - The entrepreneur in his community. In J. Goody (Ed.), Changing social structure in Ghana (pp. 1-35). London: International African Institute.

Hegelund, A. (2005). Objectivity and subjectivity in the ethnographic method. Qualitative Health Research, 15, 647-668.

Heider, E. R. (1972). Probabilities, sampling, and ethnographic method: The case of Dani colour names. Man (N.S.), 7, 448-466.

Helin, J. (2011). Living moments in family meetings: A process study in the family business context. Unpublished doctoral dissertation, Jönköping International Business School. 
Hodson, R. (1998). Organizational ethnographies: An underutilized resource in the sociology of work. Social Forces, 76, 1173-1208.

Hollos, M., \& Larsen, U. (2004). Which African men promote smaller families and why? Marital relations and fertility in a Pare community in Northern Tanzania. Social Science and Medicine, 58, 1733-1749.

Holy, L. (1996). Anthropological perspectives on kinship. London: Pluto.

Hunt, S. D. (2003). Controversy in marketing theory: For reason, realism, truth, and objectivity. Armonk, NY: M. E. Sharpe.

Jackson, J. L. Jr. (2004). An ethnographic filmflam: Giving gifts, doing research, and videotaping the native subject/object. American Anthropologist, 106, 32-42.

Jacobs-Huey, L. (2002). The natives are gazing and talking back: Reviewing the problematics of positionality, voice, and accountability among "native" anthropologists. American Anthropologist, 104, 791-804.

Johannisson, B. (2002). Energising entrepreneurship: Ideological tensions in the medium-sized family business. In D. Fletcher (Ed.), Understanding the small family business (pp. 4657). London: Routledge.

Johnson, A., \& Johnson, O. R. (1990). Quality into quantity: The measurement potential of fieldnotes. In R. Sanjek (Ed.), Fieldnotes: The makings of anthropology (pp. 161-186). Ithaca, NY: Cornell University Press.

Jones, A. M. (2006). Culture, identity, and motivation: The historical anthropology of a family firm. Culture and Organization, 12, 169-183.

Jordan, A. T. (2010). The importance of business anthropology: Its unique contribution. International Journal of Business Anthropology, 1, 7-17.

Kasdan, L. (1965). Family structure, migration and the entrepreneur. Comparative Studies in Society and History, 7, 345-357.

Keesing, R. M. (Ed.) (1978). 'Elota's story: The life and times of a Solomon Islands big man. New York: St. Martin's Press.

Kondo, D. K. (1990). Crafting selves: Power, gender, and discourses of identity in a Japanese workplace. Chicago: University of Chicago Press.

Kuper, A. (1999). Culture: The anthropologists' account. Cambridge, MA: Harvard University Press. 
Kuper, A. (2009). Incest and influence: The private life of bourgeois England. Cambridge, MA: Harvard University Press.

Lam, W. (2011). Dancing to two tunes: Multi-entity roles in the family business succession process. International Small Business Journal, 29, 508-533.

Lambek, M. (2011). Kinship as gift and theft: Acts of succession in Mayotte and ancient [sic] Israel. American Ethnologist, 38, 2-16.

Leach, E. R. (1961). Pul Eliya: A village in Ceylon: A study of land tenure and kinship. Cambridge, UK: Cambridge University Press.

Learned, K. E (1995). The creation of firm resources: A native ethnography. Unpublished doctoral dissertation, Texas Tech University.

Lett, J. (1997). Science, reason, and anthropology: The principles of rational inquiry. Lanham, MD: Rowman \& Littlefield.

Locke, K. (2011a). Field research practice in management and organization studies: Reclaiming its tradition of discovery. Academy of Management Annals, 5, 613-652.

Locke, K. (2011b). Looking for what we have a case of. Qualitative Research in Organizations and Management, 6, 88-92.

Lomnitz, L. A., \& Pérez-Lizaur, M. (1987). A Mexican elite family, 1820-1980: Kinship, class and culture. Princeton, NJ: Princeton University Press.

Malkki, L. H. (2007). Tradition and improvisation in ethnographic field research. In A. Cerwonka \& L. H. Malkki (Eds.), Improvising theory: Process and temporality in ethnographic fieldwork (pp. 162-187). Chicago: University of Chicago Press.

Marcus, G. E., \& Hall, P. D. (1992). Lives in trust: The fortunes of dynastic families in late twentieth century America. Boulder, CO: Westview.

McDonough, G. W. (1986) Good families of Barcelona: A social history of power in the industrial era. Princeton, NJ: Princeton University Press.

Meisch, L. A. (2002). Andean entrepreneurs: Otavalo merchants and musicians in the global arena. Austin: University of Texas Press.

Mills, C. W. (2000, originally 1959). The sociological imagination. New York: Oxford University Press.

Moffatt, M. (1992). Ethnographic writing about American culture. Annual Review of Anthropology, 21, 205-229. 
Morrill, C., \& Fine, G. A. (1997). Ethnographic contributions to organizational sociology. Sociological Methods and Research, 25, 424-451.

Mosse, D. (2006). Anti-social anthropology: Objectivity, objection, and the ethnography of public policy and professional communities. Journal of the Royal Anthropological Institute (N.S.), 12: 935-956.

Mulligan, T. M. (1987). The two cultures in business education. Academy of Management Review, 12, 593-599.

Nordqvist, M., Hall, A., \& Melin, L. (2009). Qualitative research on family businesses: The relevance and usefulness of the interpretive approach. Journal of Management \& Organization, 15, 294-308.

Ortner, S. B. (1996). Making gender: The politics and erotics of culture. Boston: Beacon Press.

Oxfeld, E. (1993). Blood, sweat, and mahjong: Family and enterprise in an overseas Chinese community. Ithaca, NY: Cornell University Press.

Parsons, T. (1951). The social system. New York: Free Press.

Patterson, M. (2005). Introduction: Reclaiming paradigms lost. Australian Journal of Anthropology, 16, 1-17.

Peletz, M. G. (1995). Kinship studies in late twentieth century anthropology. Annual Review of Anthropology, 24, 343-372.

Pine, F. (1996). Family. In A. Barnard \& J. Spencer (Eds.), Encyclopedia of social and cultural anthropology (pp. 223-228). London: Routledge.

Ragin, C. C. (1992). Cases of "what is a case?" In C. C. Ragin \& H. S. Becker (Eds.), What is a case? Exploring the foundations of social inquiry (pp. 1-17). New York: Cambridge University Press.

Ram, M. (1994). Managing to survive: Working lives in small firms. Oxford, UK: Blackwell.

Robertson, A. F. (1991). Beyond the family: The social organization of human reproduction. Berkeley: University of California Press.

Rosa, P., \& Caulkins, D. D. (2013). Entrepreneurship studies. In D. D. Caulkins \& A. T. Jordan (Eds.), A companion to organizational anthropology (pp. 98-121). New York: Wiley.

Rutherford, D. (2010). Kinship, capital, and the unsettling of assumptions: Contemporary anthropology and the study of family enterprise and entrepreneurship. In A. Stewart, G. T. Lumpkin, \& J. A. Katz (Eds.), Entrepreneurship and Family Business (pp. 277-283). Bingley, UK: Emerald. 
Ryan, G. W., \& Bernard, H. R. (2006). Testing an ethnographic decision tree model on a national sample: Recycling beverage cans. Human Organization, 65, 103-114.

Sangren, P. S. (2009). "Masculine domination", desire and Chinese patriliny. Critique of Anthropology, 29, 255-278.

Sanjek, R. (1990a). On ethnographic validity. In R. Sanjek (Ed.), Fieldnotes: The makings of anthropology (pp. 385-418). Ithaca, NY: Cornell University Press.

Sanjek, R. (1990b). The secret life of fieldnotes. In R. Sanjek (Ed.), Fieldnotes: The makings of anthropology (pp. 187-270). Ithaca, NY: Cornell University Press.

Scandura, T. A., \& Williams, E. A. (2000). Research methodology in management: Current practices, trends, and implications for future research. Academy of Management Journal, $43,1248-1264$.

Scheffler, H. W. (2001). Filiation and affiliation. Boulder, CO: Westview.

Scheffler, H. W. (2010). Kinship and gender. In A. Stewart, G. T. Lumpkin, \& J. A. Katz (Eds.), Entrepreneurship and Family Business (pp. 285-290). Bingley, UK: Emerald.

Schneider, D. M. (1968). American kinship: A cultural account. Chicago: University of Chicago Press.

Schneider, D. M. (1995). Schneider on Schneider: The conversion of the Jews and other anthropological stories as told to Richard Handler. Durham, NC: Duke University Press.

Segalen, M. (1986). Historical anthropology of the family. New York: Cambridge University Press.

Shapiro, W. (1997). Marriage systems. In T. Barfield (Ed.), The Dictionary of Anthropology (pp. 304-307). Oxford, UK: Blackwell.

Shimizu, A. (1991). On the notion of kinship. Man (N.S.), 26, 377-403.

Song, M. (1999). Helping out: Children's labor in ethnic businesses. Philadelphia; Temple University Press.

Spradley, J. P. (1979). The ethnographic interview. New York: Holt, Rinehart \& Winston.

Stafford, C. (2000). Chinese patriliny and the cycles of yang and laiwang. In J. Carsten (Ed.), Cultures of Relatedness (pp. 37-54). New York: Cambridge University Press.

Stebbins, R. A. (2001). Exploratory research in the social sciences. Thousand Oaks, CA: Sage. 
Stewart, A. (1990). The bigman metaphor for entrepreneurship: A "library tale" with morals on alternatives for further research. Organization Science, 1, 143-159.

Stewart, A. (1998). The ethnographer's method. Newbury Park, CA: Sage.

Stewart, A. (2003). Help one another, use one another: Toward an anthropology of family business. Entrepreneurship Theory and Practice, 27(4), 383-396.

Stewart, A. (2008). Who could best complement a team of family business researchers, scholars down the hall or in another building? Family Business Review, 21, 279-293.

Stewart, A. (2010). Sources of entrepreneurial discretion in kinship systems. In A. Stewart, G. T. Lumpkin, \& J. A. Katz (Eds.), Entrepreneurship and Family Business (pp. 291-313). Bingley, UK: Emerald.

Stewart, A., \& Hitt, M. A. (2012). Why can't a family business be more like a non-family business: Modes of professionalization in family firms. Family Business Review, 25, 5886.

Stewart, A., \& Miner, A. S. (2011). The prospects for family business in research universities. Journal of Family Business Strategy, 2, 3-14.

Stockard, J. E. (2002). Marriage in culture: Practice and meaning across diverse societies. New York, Wadsworth.

Stone, L. (2010). Kinship and gender, $4^{\text {th }}$ Ed. Boulder, CO: Westview.

Sunderland, P. L., \& Denny, R. M. (2007). Doing anthropology in consumer research. Walnut Creek, CA: Left Coast Press.

Tsing, A. (2005). Friction: An ethnography of global connection. Princeton, NJ: Princeton University Press.

Urban, G. (1999). The role of comparison in the light of the theory of culture. In J. R. Bowen \& R. Peterson (Eds.), Critical comparisons in politics and culture (pp. 90-109). New York: Cambridge University Press.

Van Maanen, J. (1975). Police socialization: A longitudinal examination of job attitudes in an urban police department. Administrative Science Quarterly, 20, 207-220.

Van Maanen, J. (2011). Tales of the field: On writing ethnography, $2^{\text {nd }}$ Ed. Chicago: University of Chicago Press.

Van Vleet, K. E. (2008). Performing kinship: Narrative, gender, and the intimacies of power in the Andes. Austin: University of Texas Press. 
Viazzo, P. P., \& Lynch, K. A. (2002). Anthropology, family history, and the concept of strategy. International Review of Social History, 47, 423-452.

Wagner, J. (1979). The humanistic perspective in anthropology: A brief overview. In B. T. Grindal \& D. M. Warren (Eds.), Essays in humanistic anthropology: A festschrift for David Bidney (pp. 3-12). Washington, DC: University Press of America.

Wallman, S. (1975). Kinship, a-kinship, anti-kinship: Variations in the logic of kinship situations. Journal of Human Evolution, 4, 331-341.

Watson, R. S. (1985). Inequality among brothers: Class and kinship in South China. New York: Cambridge University Press.

Weick, K. E. (1979). The social psychology of organizing (2 ${ }^{\text {nd }} E d$.). Reading, MA: AddisonWesley.

Werner, O. (1998). Do we need standards for ethnography? Field Methods, 10(1), 1-3.

Werner, O., \& Bernard, H. R. (1994). Ethnographic sampling. Cultural Anthropology Methods, $6(7), 7-9$.

White, D. R., \& Johansen, U. C. (2006). Network analysis and ethnographic problems: Process models of a Turkish nomadic clan. New York: Lexington.

White, D. R., \& Jorion, P. (1996). Kinship networks and discrete structure theory: Applications and implications. Social Networks, 18, 267-314.

Wigren, C. (2007). Assessing the quality of qualitative research in entrepreneurship. In H. Neergaard \& J. P. Ulhøi (Eds.), Handbook of qualitative research methods in entrepreneurship (pp. 383-405). Northampton, MA: Edward Elgar.

Wolcott, H. F. (1994). Transforming qualitative data. Thousand Oaks, CA: Sage.

Wong S.-L. (1988). Emigrant entrepreneurs: Shanghai industrialists in Hong Kong. Hong Kong: Oxford University Press.

Yan, Y. (2001). Practicing kinship in rural north China. In S. Franklin \& S. McKinnon (Eds.), Relative values: Refiguring kinship studies (pp. 224-245). Durham, NC: Duke University Press.

Yanagisako, S. J. (1978). Variance in American kinship: Implications for cultural analysis. American Ethnologist, 5, 15-29.

Yanagisako, S. J. (1979). Family and household: The analysis of domestic groups. Annual Review of Anthropology, 8, 161-205. 
Yanagisako, S. J. (2002). Producing culture and capital: Family firms in Italy. Princeton, NJ: Princeton University Press. 